\title{
EgyptianJournalofMicrobiology

\author{
http://ejm.journals.ekb.eg/
}

\section{Effect of Vital Inoculations and Different Nitrogen Forms Fertilizer on the Quality and Productivity of Sunflower Plant under New Valley Conditions}

Mahmoud Ali Mohammed El Sayed

Soil Fertility and Microbiology Department, Desert Research Centre (DRC), Cairo, Egypt.

\begin{abstract}
$\mathbf{T}$ HIS RESEARCH work was carried out at the new valley area, which is characterized by hot atmospheric conditions. In other words, plants cultivated at that area will definitely need help to overcome the adverse conditions prevailing in that experimental area. Fertilizer management is believed to be a good vehicle for providing sufficient nutrition to the grown plants. Encompassing combinations of mineral $\mathrm{N}$ fertilizer forms and free-living atmospheric $\mathrm{N}$ fixer organisms, fertilizer management is thought of to be a helpful tool to achieve remedial target anticipated from plants grown under the conditions of the experimental area. The combination treatment composed of applying ammonium sulfate (AS) at $60 \mathrm{~kg} \mathrm{~N} / \mathrm{fed}$ and inoculating with bio-fertilizer mixture of Azotobacter chroococcum and Azospirillum lipoferum was found to be significantly the best fertilizer management regime for the study area based on the findings of the current work. This combination treatment could produce the highest seed and oil yields of sunflower plants when compared with other combination treatments in both seasons of study. Fertilizer management regime in the current work depicted experimenting with combinations of mineral $\mathrm{N}$ forms applied at two rates and combined with inoculation with Azotobacter chroococcum, Azospirillum lipoferum and their mixture. The objective of the current research work is mainly to figure out a fertilizer combination treatment to help sunflower plants overcome the harsh conditions prevailing in the study area.
\end{abstract}

Keywords: Bio-fertilizers, Microbial activity, Nitrogen fertilizers, Sunflower, Yield components.

\section{Introduction}

Sunflower (Helianthus annuus L.) seeds contain $38-53 \%$ oil which is characterized by high content of unsaturated fatty acids and very low content of cholesterol (Abdel-Motagally \& Osman, 2010). Nitrogen is the top most important needed nutrient that plays a major role in enlarging crop yield in agriculture. Therefore, nitrogen fertilizers such as ammonium sulfate (AS), ammonium nitrate (AN), and urea have been extensively used in modern agriculture. These fertilizers are generally oxidized to nitrate via nitrite by nitrifying microorganisms in the agricultural field (Isobe \& Ohte, 2014). As N enhances yield components and yield of crops, mineral nitrogen forms of ammonium sulfate (AS) and ammonium nitrate (AN) were developed to help attain higher yields of world food, then an organic nitrogen form of urea was recruited to help achieve the same purpose. AS is highly soluble and can be easily vulnerable to leaching with the soil water percolating down the rhizosphere and out of the reach of plant roots if applied in excess to plant needs or when irrigation water is applied in surplus to soil holding capacity. In salt affected soils especially with high $\mathrm{pH}$ and high degrees of temperature, ammonium is liable to volatility. Therefore, AS is prone to low use efficiency nitrogen fertilizer.

With regard to nitrate-N fertilizer, besides being highly soluble as compared with AS, it contaminates ground and surface water due to 
nitrate leaching and loss from the agricultural field through de-nitrification by soil anaerobic bacteria (Ju et. al., 2009). Contamination due to nitrate escaping to drainage system and ground water is actually serious where it kills living organisms with especial reference to humans where a concentration of $10 \mathrm{mg}$ nitrate/liter was reported to be highly toxic to human and cause intestinal troubles and may lead to death. Lucas \& Vitosh (1984) ranked mineral fertilizers according to their salt index, which refers to the damage they could cause to plants relative to that by an equal weight of sodium nitrate. AS, AN, $\mathrm{CN}$ and $\mathrm{UN}$ had salt index values of $0.74,1.05$, 0.65 and 0.75 , respectively. It can be seen that AN proved to be the strongest in harming the grown plants when compared with AS and urea.

Generally, volatility of prices, transportation, and storage costs of chemical fertilizers and endangering human health imposed the use of manure for soil fertility which improves soil fertility, increases water-holding capacity, decreases soil erosion, improves amount of oxygen, and promotes beneficial organisms and productivity (Hamza \& Abd-Elhady, 2010). Munir et al. (2007) found that highest seed oil content and oil yield were produced from sunflower plants which received $30 \mathrm{~kg} \mathrm{~N} / \mathrm{fed}$ of AS, AN, and urea applied either alone or in combination with 20 or $30 \mathrm{~m}^{3}$ farmyard manure. In other words, the application of organic manure may help stop fertilizer losses through leaching. In addition, short irrigation periods at volumes that are just enough to satisfy plant needs of water absorption. Such amounts of irrigation water leaves no extra water to move below the rhizosphere.

FAO (1991) reported that urea could not provide furrow cultivated plants with readily available nitrogen when compared with AS, $\mathrm{AN}$, or $\mathrm{CN}$. This was referred to the chemical and biological reactions that urea had to undergo in the soil, as well as to its movement in the soil profile down below the root zone. While, Nicoulaud \& Bloom (1996) concluded that urea can be used to supply part of the $\mathrm{N}$ required for plant growth and that failure of urea to promote rapid growth is probably due to its phyto-toxicity and not to $\mathrm{N}$ deprivation. This was also referred to that $\mathrm{AS}$ resulted in a significant increase in soil acidity (lower $\mathrm{pH}$ ) compared with ammonium nitrate (AN) or urea.
To avoid the troubles occurring from the application of AS, AN, and free urea, application of slow release fertilizers deemed to be necessary. Urea was coated with various substances amongst which is formaldehyde to protect the urea molecule from the attack of microbial populations existing in the rhizosphere and enable a slow release of nitrogen into the soil during the crop-growing season. The use of controlledrelease nitrogen fertilizers is mainly based on the principle of nitrogen utilization efficiency. Such efficiency will definitely decrease in the case of urea coated with formaldehyde owing to elongating the time required by microbial population to hydrolyze the coating then reach the urea molecule and start to release $\mathrm{N}$ from it. The delay of $\mathrm{N}$ release will not cope with plant needs especially during fast growth stages.

With respect to bio-fertilizers, they contain useful microorganisms, which could colonize in the rhizosphere and promote plant growth through increasing the supply or availability of essential nutrients to plants (Vessey, 2003). Mehran et al. (2011) indicated that manure significantly affected grain yield $(\mathrm{P} \leq 0.01)$; the highest grain yield was achieved in the interaction of manure $\times$ Azotobacter $\times$ Pseudomonas (4.556ton sunflower seeds/ha). They also added that seed yield was not significantly affected by the microorganisms when added alone. Abd El-Rahman et al. (2016) partially substituted the recommended mineral $\mathrm{N}$ rate of $30 \mathrm{~kg} \mathrm{~N} / \mathrm{fed}$ with organic $\mathrm{N}$ fertilizer as compost combined with biofertilizer. Their results revealed that application of $15 \mathrm{~kg} \mathrm{~N} / \mathrm{fed}$ $+25 \%$ compost + Bio significantly improved yield and yield attributes and protein and oil yields as compared to $100 \%$ compost or $30 \mathrm{~kg}$ $\mathrm{N} /$ fed alone. Integrating mineral-N with $25-50 \%$ compost always gave higher values than those obtained with full mineral or organic applied separately. They also found that highest seed oil percentage was recorded when plants were fed $100 \%$ compost + Bio treatment followed by feeding with $7.5 \mathrm{~kg} \mathrm{~N} / \mathrm{fed}+75 \%$ compost. Highest seed oil yield was recorded when feeding with $15 \mathrm{~kg} \mathrm{~N} /$ fed $+50 \%$ compost followed by $15 \mathrm{~kg} \mathrm{~N} /$ fed $+25 \%$ compost + Bio. Their study points to the need for integration among mineral nitrogen, organic fertilizer, and biofertilizer to attain the highest possible sunflower seed and oil yields. The biofertilizer applied in their work contained $10^{8} \mathrm{CFU} \mathrm{ml}^{-1}$ from each bacterium of Azotobacter and Azospirillum. This treatment points to the 
benefits of coexistence of both microorganisms together and saving considerable amounts of mineral nitrogen.

Kargar et al. (2014) stated that about $90 \%$ of nitrogen fixation is performed by microorganisms. In addition, Azotobacters are important free-living nitrogen-fixing bacteria. They investigated the role of Azotobacter chrococcum and Azotobacter paspali in the growth and productivity of wheat. They isolated the most active Azotobacter chrococcum and Azotobacter paspali in fixation of nitrogen in different wheat fields using Winogradskii culture medium. There randomized study was performed in six replications at outdoors considering the following factors; urea at three levels (no urea, $100 \mathrm{mg}$ urea per $\mathrm{kg}$ soil, and $200 \mathrm{mg}$ urea per $\mathrm{kg}$ soil), and 3- bacteria type at four levels (no bacteria, Azotobacter paspali alone, Azotobacter chrococcum alone, and a mix of both bacteria). Findings: The highest wheat response was obtained with Azotobacter chrococcum and Azotobacter paspali. They also found that the difference between various levels of nitrogen fertilizer was significant at 5\% level. They suggested that the studied region's indigenous Azotobacter chrococcum enhanced more wheat growth through nitrogen fixation compared to the other Azotobacter due to calcareous soil and warm and dry weather of the Province. They also stated that organic compounds such as animal manure degrades gradually and enhances the growth and stimulate nitrogen fixation by free-living bacteria such as Azotobacters. The indigenous Azotobacter chrococcum can also be isolated and used for biologic fertilizers to improve crop yield.

From another stand point, Herrera et al. (2016) reviewed knowledge about technologies for $\mathrm{N}$ fertilization with potential to increase $\mathrm{N}$ use efficiency and reduce its negative effects on the environment. They stated that classic inorganic sources such as urea and ammonium sulfate were the major sources utilized, while controlled $\mathrm{N}$ release fertilizers have not been significantly adopted for cereals and oil crops. They pointed to that microorganisms, with the exception of Rhizobium sp. in soybeans, are also not widely used those days (e.g., plant growthpromoting bacteria and Cynobacteria). The interest in implementing new $\mathrm{N}$ fertilization knowledge is stimulating the development of sensors to diagnose the $\mathrm{N}$ status and decision support systems for integrating several variables to optimize sources, rates and methods of application. Furthermore, increasing concern about the environmental consequences of $\mathrm{N}$ may facilitate the implementation of innovations outside the farm such as more effective regulations to guide $\mathrm{N}$ fertilization and methods to manufacture $\mathrm{N}$ fertilizers that are more energyefficient and less $\mathrm{CO}_{2}$ equivalent emitting.

Gendy et al. (2013) carried out a field experiment during two successive seasons, 2011 and 2012 aiming to study the effect of utilizing different sources of nitrogen (ammonium nitrate $\mathrm{NH} 4 \mathrm{NO} 3$ or ammonium sulphate $\left(\mathrm{NH}_{4}\right) 2 \mathrm{SO}_{4}$ with or without adding bio-fertilizers (biogein at $2 \mathrm{~kg} /$ fed., nitrobein at $2 \mathrm{~kg} / \mathrm{fed}$., or biogen at $1 \mathrm{~kg} /$ fed., + nitrobein at $1 \mathrm{~kg} / \mathrm{fed}$.) as well as their interaction on the plant growth, seed yield, total protein and total guaran content in seeds as well as some chemical contents in leaves. Their results revealed that different sources of nitrogen or bio-fertilizers increased the growth parameters; i.e., plant height, number of branches per plant and dry weight of aerial part and leaves per plant, as well as number of pods/plant, weight of seeds ( $\mathrm{gm} / \mathrm{plant}$ or $\mathrm{kg} / \mathrm{fad}$.), and chemical constituents such as total protein and N, P, K compared to untreated plants. They stated that fertilizing guar plants with ammonium sulphate was the most effective in raising the productivity of seeds and the content and yield of guaran and chemical composition than ammonium nitrate. Treating plants by bio-fertilizer (mixture of biogein+nitrobein) was the most effective in this concern followed by nitrobein and then biogein. The interaction treatment of ammonium sulphate at $60 \mathrm{~kg} \mathrm{~N} /$ fed., + bio-fertilizer (biogein at $1 \mathrm{~kg} /$ fed., + nitrobein at $1 \mathrm{~kg} / \mathrm{fed}$.) gave the best result in this concern with significant differences if compared to the control and the other treatments under study in both seasons.

The aim of this study is to investigate the integrated effects of mineral-N fertilizers; ammonium sulfate and ammonium nitrate, and that of organic-N urea-formaldehyde all applied at two rates without or with the inoculation with bio-fertilizers; Azotobacter chroococcum and Azospirillum lipoferum and both together, on sunflower seed and oil yields, and quality, as well. 


\section{Materials and Methods}

\section{Agricultural experiment}

A field experiment was conducted in a sandy soil at El-Monira village, El-Kharga Oasis of the GIS indices of 30.53 longitude, 25.45 latitude and $78.8 \mathrm{~m}$ latitude at the New Valley Governorate during two successive cropping seasons of 2016 and 2017. The major objective of the current research was to study the response of sunflower plants to mineral nitrogen fertilizers; ammonium sulfate (AS), ammonium nitrate $\mathrm{AN}$ ), and urea formaldehyde (U), applied at two levels; 60 and $30 \mathrm{~kg} \mathrm{~N} /$ feddan ( 1 feddan= 0.42 hactar $)$. All of the previous six combination treatments were applied without (control) and with being inoculated by Azotobacter chroococcum, Azospirillum lipoferum, and their mixtures.

To apply the adopted microorganisms, bacterial concentration of the applied suspensions was adjusted to $10^{8} \mathrm{CFU} / \mathrm{ml}$ for the three microbial treatments. Sunflower seeds were wetted before planting with bacterial suspensions at the rate of $250 \mathrm{ml}$ suspension/1250gm seeds for three hours before planting. Carboxy methyl cellulose $0.5 \%$ was used as an adhesive agent; i.e. spreading agent. The previous pre-planting treatment with microbial suspensions represents half dose of the biofertilizer treatments. The other half was applied in the form of spray using a back-mounted sprayer to soil down plants aging one month after seeding.

With regard to mineral fertilizers, they were applied in three doses; after 30 (at vigorous vegetative growth and plant elongation growth stage), 45 (at flowering), and 60 days (at head maturity and seed filling growth stage) from seeding. The three mineral nitrogen fertilizers; AS, AN, and U-formaldehyde, were applied in the form of solid fertilizer about $7 \mathrm{~cm}$ away from plant stem to avoid harming those plants, except for urea formaldehyde which was applied immediately down the plants close to the stems owing to the slow solubility of that fertilizer and expecting no harm to the plants. The three application doses were not equal, with the first being the least because the plants were not in big need for $\mathrm{N}$ nutrient at that dose. The second dose of fertilizer $\mathrm{N}$ was the greatest because it coped with the fast growth time. The third dose coincided with the heading growth stage which witness pollination and seed production.
With regard to phosphorus fertilizer application, it was applied at the rate of $45 \mathrm{~kg} \mathrm{P} / \mathrm{fed}$ with the applied organic manure which was added at the rate $20 \mathrm{~m}^{3} /$ feddan 15 days prior to seeding. The applied amounts were metered per dripper line and were to be applied in the furrow that was manually dug, then the furrow was filled with the dugout soil. This practice was achieved the same for all treatments.

With respect to potassium fertilizer, it was applied the same to all combination treatments in all replicates in two equal doses after 45 and 60 days from seeding. The applied dose was to be calibrated per plant and applied $5-7 \mathrm{~cm}$ away from plants stems to avoid plant burn damage.

Farm yard manure was broadcast applied and incorporated into the soil surface layer by hand hoeing, then the dripper lines were straight back to their places. A quick false irrigation was applied on to the experimental dripper lines through the drip irrigation network 15 days before seeding to allow the exposure of weeds that may be existing in the soil and the added farm manure to combat them.

Seeding rate was $5 \mathrm{~kg} / \mathrm{fed}$. On the seeding day, 3-4 seeds were to be placed in hills $30 \mathrm{~cm}$ apart along the dripper lines. After germination, number of plants was thinned to 2 plants per hill to achieve a full $100 \%$ stand at the beginning of the cultivation season. Owing to the fine textured soil nature (around $48 \%$ as silt + clay), drip irrigation was to be practiced every six-day period with short application period each time to avoid loss of soluble fertilizers with the soil water percolating down the rhizosphere, i.e. beyond the plants root system.

Some physical and chemical analyses of both the adopted soil and irrigated water:

Some physical and chemical analyses of the experimental field soil were achieved according to Page et al. (1982) and presented in Table 1. In addition, chemical analyses of irrigation water were depicted in the same table. The latter analyses exhibited that the irrigation water had $\mathrm{pH}$ value, 7.5 and EC, $1.46 \mathrm{dS} . \mathrm{m}^{-1}$.

\section{Test plant}

Seeds of the adopted test plant (Sunflower cultivar Sakha 53 (Helianthus annuus L.) were purchased from the Oil Crops Research Institute, Agricultural Research Center, Giza, Egypt. 
TABLE 1. Analysis of experimental soil to a $30 \mathrm{~cm}$ depth and irrigation water

\begin{tabular}{|c|c|c|c|c|c|c|c|c|c|c|c|c|}
\hline & & & & \multicolumn{6}{|c|}{ Physical analysis \% } & \multirow{2}{*}{\multicolumn{3}{|c|}{ Soil texture }} \\
\hline & & & & Sand & \multicolumn{2}{|c|}{ Silt } & \multicolumn{3}{|c|}{ Clay } & & & \\
\hline & & & & 52.95 & \multicolumn{2}{|c|}{21.51} & \multicolumn{3}{|c|}{25.54} & \multicolumn{3}{|c|}{ Sandy clay loam } \\
\hline \multicolumn{13}{|c|}{ Chemical analysis } \\
\hline \multirow{2}{*}{ pH } & \multirow{2}{*}{$\begin{array}{c}\text { E.C } \\
\text { dS.m }{ }^{-1}\end{array}$} & \multirow{2}{*}{$\begin{array}{c}\mathrm{CaCO}_{3} \\
\%\end{array}$} & \multirow{2}{*}{$\begin{array}{c}\text { O.M } \\
\%\end{array}$} & \multirow{2}{*}{$\begin{array}{c}\text { T.N } \\
\%\end{array}$} & \multicolumn{4}{|c|}{ Cations meq/L } & \multicolumn{4}{|c|}{ Anions meq/L } \\
\hline & & & & & $\mathrm{Ca}^{+2}$ & $\mathbf{M g}^{+2}$ & $\mathbf{N a}^{+}$ & $\mathbf{K}^{+}$ & $\mathrm{CO}_{3}^{-2}$ & $\mathrm{HCO}_{3}^{-}$ & $\mathrm{Cl}^{-}$ & $\mathrm{SO}_{4}^{-2}$ \\
\hline 8.64 & 8.21 & 4.34 & 0.58 & 0.09 & 25.2 & 8.2 & 43.4 & 5.3 & 0.9 & 15.9 & 50.9 & 14.4 \\
\hline \multicolumn{13}{|c|}{ Chemical analysis of irrigation water } \\
\hline pH & \multicolumn{3}{|c|}{ E.C dS.m $\mathbf{m}^{-1}$} & & $\mathbf{C a}^{+2}$ & $\mathbf{M g}^{+2}$ & $\mathbf{N a}^{+}$ & $\mathbf{K}^{+}$ & $\mathrm{CO}_{3}^{-2}$ & $\mathrm{HCO}_{3}^{-}$ & $\mathrm{Cl}^{-}$ & $\mathrm{SO}_{4}^{-2}$ \\
\hline 7.5 & \multicolumn{3}{|l|}{1.46} & & 5.42 & 3.24 & 5.43 & 0.27 & 1.65 & 2.18 & 4.2 & 6.16 \\
\hline
\end{tabular}

\section{Microorganisms}

Bacterial isolates recruited in the current experiment were isolated from salt affected soils at newly reclaimed sandy areas. The isolated bacteria were identified as being Azotobacter chroococcum and Azospirillum lipoferum according to Bergey's Systematic Bacteriology (Krieg $\&$ Dobereiner, 1984).

Plant growth promoting properties of bacterial isolates: Agronomic data recoded:

Soil biological activity

Enumeration of microorganisms in soil samples were carried out by the most probable number (MPN) technique. One milliliter successive dilutions of $10^{3}, 10^{4}$, and $10^{5}$ were attained. Soil samples were to be transferred to test tubes containing semi-solid $\mathrm{NFb}$ medium and plates of Ashby medium for Azospirillum and Azotobacter isolates, respectively. Tubes and plates were then incubated under suitable temperature. Microorganisms were identified based on cultural, morphological and biochemical characteristics as per Bergey's Manual of Systematic Bacteriology.

Bacterial population $=($ MPN value $\times$ middle dilution $\times$ middle dilution used)/ (Dry weight of the soil sample)

\section{Determination of microbial activity}

Counts of microorganisms were estimated by the dilution plate technique methods. The following microbial analyses; total Azotobacter count (Counts $\mathrm{x} 10^{4} \mathrm{CFU} \mathrm{\textrm {g } ^ { - 1 }}$ dry soil) and Azospirilla densities (Counts $\mathrm{x} \quad 10^{4} \mathrm{CFU} \mathrm{g}^{-1}$ dry soil) were carried out in all soil samples.
Dehydrogenase activity ( $\mu \mathrm{g} \mathrm{TPF} \mathrm{g}^{-1}$ dry soil $24 \mathrm{hrs}$ ) in the rhizosphere soil was determined according to Pramer \& Schmidt (1964) and Thalmann (1967). Production of ammonia was determined according to Cappuccino \& Sherman (1992).

\section{Soil analyses}

Soil samples were collected from each dripper line at the same time of plant sampling, air-dried, passed through a $2 \mathrm{~mm}$ sieve and kept for physical and chemical analyses. Particle size distribution was determined using the pipette method according to Jackson (1973). Electrical conductivity (EC) and soil $\mathrm{pH}$ was determined in a 1: 2.5 soil to water extract using conductivity meter and Beckman $\mathrm{pH}$ meter, respectively according to Jackson (1973). Organic carbon content was determined by Walkley and Black's wet oxidation method (Walkley \& Black, 1934). Available potassium was extracted by neutral normal ammonium acetate method and measured by flame photometer. Available $\mathrm{P}$ was extracted using $0.5 \mathrm{M} \mathrm{NaHCO}_{3}$ at $\mathrm{pH} 8.5$ according to Olsen et al. (1982) and measured colorimetrically using the chlorostannus phosphomolybdic-sulfuric acid method as described by Jackson (1973).

\section{Chemical composition of plants and seeds:}

Half gram of the powdered plant samples was digested using tertiary acid mixture $\left(\mathrm{HClO}_{4}+\mathrm{HNO}_{3}+\mathrm{H}_{2} \mathrm{SO}_{4}\right)$ according to Jackson (1973). Phosphorus was determined using a spectrophotometer, but $\mathrm{K}$ by a flame photometer according to Jackson (1973). Another half-gram was digested by the modified Kjeldahl method for N determination according to Jackson (1973). 


\section{Yield and yield components}

At harvest, plant height $(\mathrm{cm})$, number of leaves/ plant, seed head fresh weight $(\mathrm{g})$, seed head dry weight (g), plant weight (g), seeds weight (g)/plant, and seed head diameter $(\mathrm{cm})$, then seed yield $(\mathrm{kg} /$ feddan) ( 1 feddan $=0.42$ hactare $)$ was calculated in both seasons of the current study. In addition, oil production (g/plant) was also assessed and calculated as $\mathrm{kg} /$ feddan. To evaluate effects of the applied treatments on seed quality, seed mineral content of $\mathrm{N}$, $\mathrm{P}$, and $\mathrm{K}$ was achieved.

Soil physical and chemical properties of the experimental site were measured according to Page et al. (1982). Soil texture was achieved by dry sieving analysis. In soil paste extract, soil $\mathrm{pH}$, $\mathrm{EC}$, and water soluble cations and anions were measured. Extracted $\mathrm{Na}^{+}$and $\mathrm{K}^{+}$were measured flame photometrically, $\mathrm{Ca}^{++}$and $\mathrm{Mg}^{++}$titrimetric ally using versinate, $\mathrm{HCO}_{3}{ }^{-}$titrimetric ally using dilute $\mathrm{HCl}$, and $\mathrm{Cl}^{-}$titrimetric ally using silver nitrate. Sulfate was calculated as the difference between cations and anions. Calcium carbonate content of the soil was achieved using a calcimeter. Organic matter content was also measured according to Page et al. (1982). Available N was measured according to Onken \& Sunderman (1977). Available P content was achieved according to Olsen et al. (1982), while available $\mathrm{K}$ was measured using ammonium acetate solution according to Page et al. (1982).

\section{Statistical analysis}

All dripper lines were divided into three groups of drippers according to the expected drop in the driving head along the end tail of lines. The three groups were to be sampled for three replicates, respectively. The obtained data were exposed to the analysis of variance (ANoVA) according to the statistical design of split-split plot technique in randomized complete blocks using SPSS (2014) software package. The Duncan least significant range (LSR) will be recruited to differentiate among treatment means obtained in the current work. The result of using Duncan test will show up in table cells as alphabets attached close to the right of various mean values.

\section{Results and Discussion}

\section{Soil available $N, P$, and $K$}

Initial soil available nitrogen was found to be $0.008 \%(80 \mu \mathrm{g} / \mathrm{g}$ dry soil) on the average for all soil samples collected at the time of seedbed preparation. This amount of available $\mathrm{N}$ resembles the starter dose of $\mathrm{N}$ on which the plants and microorganisms were going to start their activities. Doing so gives us the opportunity to follow up the influence of the applied treatments on the adopted test plant sunflower. Based on the analysis results no gross variations were found among the samples collected from the soil under all dripper lines. Therefore, the starter situation is not considered a source of variability.

Data in table 2 show that all applied treatments and the control enhanced soil available nitrogen content at the time of sunflower flowering above the initial content. This can be referred to a changed effect due to the application of fertilizers.

Data in Table 2 show that AS could significantly surpass AN which, in turn, surpassed ureaformaldehyde in proliferating greater available nitrogen in the rhizosphere that accommodates sunflower roots in the first season. With regard to the application rate, the higher application rate significantly proved to be better in bringing more available N. These findings coincide with those obtained by FAO (1991) which pointed to the same order for the three nitrogen fertilizer forms. In addition, data in the same table point to that the interaction between $\mathrm{N}$ sources and rate of application was significant. In other words, the three $\mathrm{N}$ forms were steadily greater with the higher $\mathrm{N}$ rate of application than with the lower one in bringing available $\mathrm{N}$ in the rhizosphere.

From Table 2, it is clear that the application of bio-fertilizers proved to be significantly beneficial over the control treatment in accumulating greater available $\mathrm{N}$ in the rhizosphere of sunflower plants in the current work. Albeit obvious, Azotobacter exceeded Azospirillum. But, applying both microbes together was much better than applying both organisms separately. Thus, including Azospirillum with Azotobacter could foster the effect of Azotobacter alone forward to a peak of influence on soil available $\mathrm{N}$ in the rhizospher of sunflower plants. These findings agree strongly with what was reported by Mehran et al. (2011) who stressed the advantages of applying both organisms together than being separately applied. Same Table 2 points also to that the interaction between $\mathrm{N}$ forms and bio-fertilizer treatments was found significant. The best combination treatment was obtained from applying AS with the mixed biofertilizer treatment of Azotobacter-Azospirillum. 
TABLE 2. Soil available N, P, and $K$ at sunflower flowering stage as affected by the applied treatments in 2016 and 2017

\begin{tabular}{|c|c|c|c|c|c|c|c|c|c|c|c|c|c|}
\hline \multirow{3}{*}{$\begin{array}{l}\mathbf{N} \\
\text { forms }\end{array}$} & \multirow{3}{*}{ Bio } & \multicolumn{4}{|c|}{ Soil av. N ( $\mu g N / g m$ soil) } & \multicolumn{4}{|c|}{ Soil av. $P(\mu g P / g m$ soil $)$} & \multicolumn{4}{|c|}{ Soil av. K (me/100gm soil) } \\
\hline & & \multirow{2}{*}{$\begin{array}{c}2016 \\
60\end{array}$} & \multicolumn{3}{|c|}{2017} & \multicolumn{2}{|c|}{2016} & \multicolumn{2}{|c|}{2017} & \multicolumn{2}{|c|}{2016} & \multicolumn{2}{|c|}{2017} \\
\hline & & & 30 & 60 & 30 & 60 & 30 & 60 & 30 & 60 & 30 & 60 & 30 \\
\hline \multirow{4}{*}{ AS } & Control & $217 \mathrm{k}$ & $184 \mathrm{~lm}$ & $226 \mathrm{q}$ & $196 \mathrm{~s}$ & $3.12 \mathrm{q}$ & $2.66 \mathrm{t}$ & $3.72 \mathrm{ij}$ & $2.90 \mathrm{p}$ & 2.141 & $2.01 \mathrm{~m}$ & $2.17 \mathrm{~lm}$ & $2.11 \mathrm{o}$ \\
\hline & Azotobacter & $392 \mathrm{~d}$ & $328 \mathrm{f}$ & $400 \mathrm{f}$ & $336 \mathrm{j}$ & $4.05 \mathrm{~g}$ & $3.59 \mathrm{i}$ & $4.58 \mathrm{e}$ & $3.82 \mathrm{hi}$ & $2.31 \mathrm{f}$ & $2.20 \mathrm{hi}$ & $2.38 \mathrm{~g}$ & $2.27 \mathrm{hi}$ \\
\hline & Azospirillum & $332 \mathrm{f}$ & $278 \mathrm{i}$ & $340 \mathrm{i}$ & $287 \mathrm{n}$ & $3.76 \mathrm{i}$ & $3.18 \mathrm{o}$ & $4.27 \mathrm{f}$ & $3.44 \mathrm{lmn}$ & $2.25 \mathrm{~g}$ & $2.15 \mathrm{jkl}$ & $2.30 \mathrm{~h}$ & $2.19 \mathrm{kl}$ \\
\hline & Mixed & $563 \mathrm{a}$ & $422 \mathrm{c}$ & 578 a & $434 \mathrm{~d}$ & $5.66 \mathrm{a}$ & $4.93 \mathrm{c}$ & $5.74 \mathrm{a}$ & $5.33 \mathrm{~b}$ & $2.87 \mathrm{a}$ & $2.60 \mathrm{c}$ & $2.98 \mathrm{a}$ & $2.71 \mathrm{c}$ \\
\hline \multirow{4}{*}{ AN } & Control & 2001 & $169 \mathrm{~m}$ & $208 \mathrm{r}$ & $176 \mathrm{u}$ & $3.00 \mathrm{r}$ & $2.21 \mathrm{u}$ & $3.42 \mathrm{mn}$ & $2.43 \mathrm{q}$ & $2.06 \mathrm{~m}$ & $1.86 \mathrm{n}$ & $2.13 \mathrm{mno}$ & $2.05 \mathrm{p}$ \\
\hline & Azotobacter & $368 \mathrm{e}$ & $297 \mathrm{~h}$ & $378 \mathrm{~h}$ & 3121 & $3.90 \mathrm{~h}$ & $3.41 \mathrm{~m}$ & $4.05 \mathrm{~g}$ & $3.75 \mathrm{i}$ & $2.24 \mathrm{~g}$ & $2.17 \mathrm{ijk}$ & $2.36 \mathrm{~g}$ & $2.22 \mathrm{jk}$ \\
\hline & Azospirillum & $313 \mathrm{fg}$ & $253 \mathrm{j}$ & $323 \mathrm{k}$ & 2610 & $3.71 \mathrm{j}$ & $3.18 \mathrm{o}$ & $3.93 \mathrm{~h}$ & 3.34 no & $2.18 \mathrm{ij}$ & 2.131 & $2.29 \mathrm{hi}$ & $2.16 \mathrm{lmn}$ \\
\hline & Mixed & $508 \mathrm{~b}$ & $388 \mathrm{~d}$ & $516 \mathrm{~b}$ & $406 \mathrm{e}$ & $5.24 \mathrm{~b}$ & $4.40 \mathrm{e}$ & $5.33 \mathrm{~b}$ & $4.80 \mathrm{~d}$ & $2.68 \mathrm{~b}$ & $2.45 \mathrm{~d}$ & $2.76 \mathrm{~b}$ & $2.66 \mathrm{de}$ \\
\hline \multirow{4}{*}{ Urea-F } & Control & 1861 & $162 \mathrm{n}$ & $191 \mathrm{t}$ & $166 \mathrm{v}$ & $2.68 \mathrm{~s}$ & $2.11 \mathrm{v}$ & $2.96 \mathrm{p}$ & $2.28 \mathrm{r}$ & $1.89 \mathrm{n}$ & $1.80 \mathrm{o}$ & $2.06 \mathrm{p}$ & $1.90 \mathrm{q}$ \\
\hline & Azotobacter & $329 \mathrm{f}$ & 291 hi & $338 \mathrm{ij}$ & $298 \mathrm{~m}$ & $3.70 \mathrm{k}$ & $3.37 \mathrm{n}$ & $3.95 \mathrm{gh}$ & $3.53 \mathrm{klm}$ & $2.23 \mathrm{gh}$ & $2.15 \mathrm{jkl}$ & $2.25 \mathrm{ij}$ & $2.19 \mathrm{kl}$ \\
\hline & Azospirillum & $302 \mathrm{gh}$ & $252 \mathrm{j}$ & 3111 & $256 \mathrm{p}$ & $3.40 \mathrm{~m}$ & $3.14 \mathrm{p}$ & $3.63 \mathrm{jk}$ & $3.27 \mathrm{o}$ & $2.16 \mathrm{jkl}$ & $2.04 \mathrm{~m}$ & $2.24 \mathrm{ij}$ & 2.12 no \\
\hline & Mixed & $490 \mathrm{~b}$ & $294 \mathrm{~h}$ & $505 \mathrm{c}$ & $386 \mathrm{~g}$ & $4.91 \mathrm{~d}$ & $4.25 \mathrm{f}$ & $5.05 \mathrm{c}$ & $4.54 \mathrm{e}$ & $2.65 \mathrm{~b}$ & $2.37 \mathrm{e}$ & $2.63 \mathrm{e}$ & $2.53 \mathrm{t}$ \\
\hline
\end{tabular}

Mean values in the above table sharing one alphabet are not significantly different

From Table 2, it is clear that the application of bio-fertilizers proved to be significantly greater with the higher rate of applying $\mathrm{N}$ forms than with the lower one. This normally point to a significant influence of the interaction between bio-fertilizer treatments and rate of application. The best combination treatment was mixed bio-fertilizer with the higher rate of applying $\mathrm{N}$ forms.

From Table 2, it is clear that the best combination treatment for accumulating soil available $\mathrm{N}$ in the rhizosphere of sunflower plants under the conditions of the current work can be figured out as the application AS at the rate of $60 \mathrm{~kg} / \mathrm{fed}$ accompanied by the application of mixed Azotobacter and Azospirillum bio-fertilization in both seasons of study season.

Data regarding soil available $\mathrm{N}$ in the second season are depicted in Table 2, from which, it can be seen that AS could significantly accumulate higher available $\mathrm{N}$ than the other two sources. By the time, the mixed application of the AS proved to be the best technique of $\mathrm{N}$ forms application when compared with the sole application of both forms alone. Regarding to the rate of application of $\mathrm{N}$ forms, the higher rate proved to be significantly better than the lower rate in proliferating more $\mathrm{N}$ in the rhizosphere of sunflower plants.
Table 2 tells also that the mixed bio-fertilizer treatment; Azotobacter + Azospirillum, proved to be significantly more active than the application of both Azotobacter and Azospirillum alone. Albeit clear, Azotobacter was better than Azospirillum when applied separately. The best treatment is that of applying AS at $60 \mathrm{kgN} / \mathrm{fed}$. In addition, same table 2 shows that the best bio-fertilizer treatment is Azotobacter + Azospirillum with AS at the $60 \mathrm{~kg}$ $\mathrm{N} /$ fed.

In conclusion, the best applied treatment was figured out to be that combined from ammonium sulfate (AS) + ammonium nitrate (AN) applied at the rate of $60 \mathrm{~kg} \mathrm{~N} / \mathrm{fed}$ with the inoculation of biological treatment that is composed of a mixture of Azotobacter chroococcum and Azospirillum lipoferum which free-living atmospheric nitrogen fixers.

With regard to effects of the applied treatments on soil available $\mathrm{P}$, data in Table 2 approximately exhibit that the same effects observed on soil available $\mathrm{N}$ showed up on soil available $\mathrm{P}$, except for the interaction between $\mathrm{N}$ sources and rate of application in the second season was not significant. This means AS was better than AN, which was, in turn better than urea-formaldehyde, irrespective of being applied at either of the two 
adopted rates. However, the higher rate proved to be significantly better than the lower one.

Same Table 2 tells also that soil available P responded significantly better with the mixed application of biological fertilizer mixture of Azotobacter \& Azospirillum. Table 2 again tells that the interaction between $\mathrm{N}$ sources and bio fertilizer and the interaction between rate of application and bio fertilizer were found significant. Consequently, the best combination treat in effecting highest soil available $\mathrm{P}$ in the rhizosphere of sunflower plants is that composed of AS at $60 \mathrm{~kg} \mathrm{~N} /$ fed with inoculation with biological fertilizer mixture of Azotobacter chroococcum and Azospirillum lipoferum.

From Table 2 trends showing up regarding soil available $\mathrm{P}$ were, more or less, the same regarding soil available $\mathrm{K}$. the interaction between $\mathrm{N}$ sources and rate could not prove to be significant in both seasons of the current study. Consequently, the best combination treat in effecting highest soil available $\mathrm{K}$ in the rhizosphere of sunflower plants is that composed of AS at $60 \mathrm{~kg} \mathrm{~N} / \mathrm{fed}$ with inoculation with biological fertilizer mixture of Azotobacter chroococcum and Azospirillum lipoferum.

Density of Azotobacter chroococcum and Azospirillum lipoferum

Initial density of total Azotobacter chroococcum counts $5.6 \times 10^{3} \mathrm{CFU} / \mathrm{g}$ dry soil at the time of seedbed preparation. While the initial density of total Azospirillum lipoferum counts $6.8 \times 10^{3} \mathrm{CFU} / \mathrm{g}$ dry soil at the time of seedbed preparation.

Data in table 3 show the influence of applied treatments on Azotobacter chroococcum and Azospirillum lipoferum at the flowering growth stage of sunflower plants in the two seasons of the current study.

Table 3 declares that AS was significantly better in effecting for highest Azotobacter densities in the rhizosphere of sunflower plants than AN, which, in turn, was significantly better than ureaformaldehyde. This result can be explained by that AS proliferated more soil available NPK in the rhizosphere area. The higher rate of applying $\mathrm{N}$ forms proved to be significantly more effective in promoting greater growth of Azotobacter. With respect to the biological performance of the two adopted microbes in the current study, it can be seen from table 3 that applying them was more promoting to Azotobacter growth in the rhizosphere as compared to the control (un-inoculated) treatment. Inoculation with Azotobacter was more promoting of its growth as compared with inoculation with Azospirillum. In addition, inoculation with a mixture of both microbes was significantly more effective in promoting Azotobacter growth in the rhizosphere.

TABLE 3. Azotobacter and azospirilla densities (counts $x 10^{4} \mathrm{CFU} / \mathrm{g}$ dry soil) in the rhizospher of sunflower at flowering stage as affected by the applied treatments in 2016 and 2017

\begin{tabular}{|c|c|c|c|c|c|c|c|c|c|}
\hline \multirow{3}{*}{$\mathbf{N}$ forms } & \multirow{3}{*}{ Bio } & \multicolumn{4}{|c|}{ Azotobacter counts $\times 10^{4} \mathrm{CFU} / \mathrm{gm}$ dry soil } & \multicolumn{4}{|c|}{ Azospirilla counts $x 1^{4} \mathrm{CFU} / \mathrm{gm}$ dry soil } \\
\hline & & \multicolumn{2}{|c|}{2016} & \multicolumn{2}{|c|}{2017} & \multicolumn{2}{|c|}{2016} & \multicolumn{2}{|c|}{2017} \\
\hline & & $60 \mathrm{~kg} \mathrm{~N}$ & $30 \mathrm{~kg} \mathrm{~N}$ & $60 \mathrm{~kg} \mathrm{~N}$ & $30 \mathrm{~kg} \mathrm{~N}$ & $60 \mathrm{~kg} \mathrm{~N}$ & $30 \mathrm{~kg} \mathrm{~N}$ & $60 \mathrm{~kg} \mathrm{~N}$ & $30 \mathrm{~kg} \mathrm{~N}$ \\
\hline \multirow{4}{*}{ AS } & Control & 361 & $34 \mathrm{~m}$ & $48 \mathrm{q}$ & $4 \mathrm{r}$ & $4.75 \mathrm{~lm}$ & $4.62 \mathrm{~m}$ & 5.471 & $5.13 \mathrm{~m}$ \\
\hline & Azotobacter & $70 \mathrm{c}$ & $71 \mathrm{c}$ & $76 \mathrm{e}$ & $79 \mathrm{c}$ & $5.87 \mathrm{~g}$ & $5.45 \mathrm{j}$ & $6.98 \mathrm{~g}$ & $6.70 \mathrm{~h}$ \\
\hline & Azospirillum & $65 \mathrm{~d}$ & $66 \mathrm{~d}$ & $72 \mathrm{~g}$ & $74 \mathrm{f}$ & $6.58 \mathrm{c}$ & $6.33 \mathrm{~d}$ & $7.62 \mathrm{de}$ & $7.30 \mathrm{f}$ \\
\hline & Mixed & $72 b$ & $75 \mathrm{a}$ & $94 \mathrm{~b}$ & $97 \mathrm{a}$ & $7.88 \mathrm{a}$ & $7.70 \mathrm{~b}$ & $9.57 \mathrm{a}$ & $9.25 \mathrm{~b}$ \\
\hline \multirow{4}{*}{$\mathrm{AN}$} & Control & $25 \mathrm{n}$ & $22 \mathrm{o}$ & $36 \mathrm{~s}$ & $34 \mathrm{t}$ & $3.88 \mathrm{o}$ & $3.67 \mathrm{op}$ & $4.65 n$ & $4.23 \mathrm{o}$ \\
\hline & Azotobacter & $56 \mathrm{~h}$ & $52 \mathrm{i}$ & $67 \mathrm{j}$ & $62 \mathrm{~m}$ & $5.62 \mathrm{hi}$ & $4.72 \mathrm{~m}$ & $6.07 \mathrm{i}$ & $5.75 \mathrm{j}$ \\
\hline & Azospirillum & $51 \mathrm{i}$ & $48 \mathrm{jk}$ & 641 & $58 \mathrm{n}$ & $5.72 \mathrm{~h}$ & $5.28 \mathrm{k}$ & $6.17 \mathrm{i}$ & $5.88 \mathrm{j}$ \\
\hline & Mixed & $65 \mathrm{~d}$ & $60 \mathrm{f}$ & $76 \mathrm{de}$ & $71 \mathrm{~h}$ & $6.18 \mathrm{e}$ & $5.92 \mathrm{fg}$ & $7.95 \mathrm{c}$ & $7.73 \mathrm{~d}$ \\
\hline \multirow{4}{*}{ Urea-F } & Control & $23 \mathrm{o}$ & $21 \mathrm{p}$ & $29 \mathrm{u}$ & $25 \mathrm{v}$ & $3.55 \mathrm{p}$ & $2.90 \mathrm{q}$ & $4.28 \mathrm{o}$ & $3.63 \mathrm{p}$ \\
\hline & Azotobacter & $51 \mathrm{i}$ & $49 \mathrm{jk}$ & $57 \mathrm{n}$ & 53 o & 4.881 & $4.42 \mathrm{n}$ & 5.431 & $5.07 \mathrm{~m}$ \\
\hline & Azospirillum & $48 \mathrm{k}$ & $47 \mathrm{k}$ & 53 o & $50 \mathrm{p}$ & $5.68 \mathrm{hi}$ & $5.20 \mathrm{k}$ & $5.80 \mathrm{j}$ & 5.401 \\
\hline & Mixed & $63 \mathrm{e}$ & $58 \mathrm{~g}$ & $69 \mathrm{i}$ & $66 \mathrm{k}$ & $6.02 \mathrm{f}$ & $5.55 \mathrm{ij}$ & $7.50 \mathrm{e}$ & $6.68 \mathrm{~h}$ \\
\hline
\end{tabular}

Mean values in the above table sharing one alphabet are not significantly different. 
The interaction of $\mathrm{N}$ forms $\mathrm{x}$ rates showed up to be significant, and so did the interaction of $\mathrm{N}$ forms $\mathrm{x}$ bio-fertilizer could prove to be significant. But, the interaction of rate $\mathrm{x}$ bio-fertilizer could not show up as being significant. This result can be explained by that the inoculated microbes could compensate for the difference between the two rates. In other words, the measured microbe Azotobacter could utilize the biological variations in the rhizosphere and went ahead to nourish irrespective of the rate of $\mathrm{N}$ forms application. The 3-variable interaction was not significant under the conditions of the current study. These findings held true for both seasons of study, except for the 3-variable interaction which was significant in the second season only. After all it can be concluded that the best combination treatment was AS at $60 \mathrm{~kg} / \mathrm{fed}$ with the inoculation with a mixture of Azotobacter chroococcum and Azospirillum lipoferum for proliferating the highest Azotobacter counts in the rhizosphere around sunflower plant roots in both seasons.

Data in Table 3 tells that approximately the same trends observed for the influences of the applied treatments on Azotobacter growth held true for the growth of Azospirillum. Exception were the interaction of rate $\mathrm{x}$ bio-fertilizer and that of the 3 -variable interaction, which were not significant in the second season only, while they were significant in the first season.

In general, Azotobacter total count was much greater than that of Azospirillum in both seasons. This result held true even with inoculation with Azospirillum. It seems as if Azotobacter can take advantage on Azospirillum and show more vigorous growth in the rhizosphere of sunflower plants. This result means that this combination treatment possesses the highest potential for fixing atmospheric nitrogen by the free living microbe Azotobacter. Logically, this result stands behind the superiority of this combination treatment in accumulating the highest available soil nitrogen in the rhizosphere of sunflower plants as shown in Table 2.

\section{$\mathrm{CO}_{2}$ evolution and dehydrogenase activity (DHA)}

Initial $\mathrm{CO}_{2}$ evolution was found to be $6.75 \mathrm{mg} /$ $100 \mathrm{~g}$ soil $/ 24 \mathrm{hrs}$, while initial dehydrogenase activity was $31.4 \mathrm{mg}$ TPF/ g dry soil/ 24hrs, at the time of preparing the seed before planting. Table 4 depicts the values of $\mathrm{CO}_{2}$ evolution as $\mathrm{mg} / 100 \mathrm{gm}$ dry soil/ $24 \mathrm{hrs}$ and exhibits the influence of the applied treatments on that process. Recruited $\mathrm{N}$ forms can be arranged in the following significant descending order AS $>\mathrm{AN}>$ urea-formaldehyde in daily $\mathrm{CO}_{2}$ evolution in the rhizosphere around sunflower plant roots. The $60 \mathrm{~kg} \mathrm{~N} /$ fed was significantly better than the lower $30 \mathrm{~kg} \mathrm{~N} / \mathrm{fed}$. The third variable bio-fertilizers showed that inoculation with either Azotobacter chroococcum or Azospirillum lipoferum alone could significantly exhibit increases above the control treatment in $\mathrm{CO}_{2}$ evolution. By the time Azotobacter surpassed Azospirillum in $\mathrm{CO}_{2}$ evolution when they are applied separately, the mixed application of microbes could perform significantly better. These findings were true in both seasons of study.

The influence of the three 2-variable interactions and the 3-variable interaction could not prove to be significant on $\mathrm{CO}_{2}$ evolution in both seasons of study, except for the $\mathrm{N}$ forms $\mathrm{x}$ bio-fertilizers was found significant in the second season only. Such result can be referred to the clear-cut effect of the sole variables levels on $\mathrm{CO}_{2}$ evolution in the rhizosphere under sunflower plants. In general, this superiority points to the highest energy that is exerted in the rhizosphere by the eruptions of microbial growth.

In conclusion, the best combination treatment was that composed of applying ammonium sulfate (AS) at the rate of $60 \mathrm{~kg} / \mathrm{fed}$ with the inoculation with a mixture of Azotobacter chroococcum and Azospirillum lipoferum for the highest $\mathrm{CO}_{2}$ evolution in the rhizosphere under sunflower plants in both seasons irrespective of the non-significant effects of some interactions.

Table 4 deals also with the measurements of dehydrogenase activity (DHA) at sunflower flowering stage as affected by the applied treatments in 2016 and 2017. It can be comprehensively said that the effects of sole variables held the same as those observed with $\mathrm{CO}_{2}$ evolution in both seasons of the current study. In other words, there existed the following significant descending order of AS> $\mathrm{AN}>$ urea-f with significantly better application rate of $60 \mathrm{~kg} \mathrm{~N} / \mathrm{fed}$ with inoculation with a mixture of Azotobacter chroococcum and Azospirillum lipoferum for the highest DHA in the rhizosphere under sunflower plants in both seasons irrespective of the non-significant effects of some interactions in both seasons of the current study. This combination treatment effected for the highest growth rate of microbes whether native in the soil and organic manure or being inoculated into the rhizosphere under sunflower plants in the new valley area. 
TABLE 4. $\mathrm{CO}_{2}$ evolution and dehydrogenase activity at sunflower flowering stage as affected by the applied treatments in 2016 and 2017

\begin{tabular}{|c|c|c|c|c|c|c|c|c|c|}
\hline \multirow{3}{*}{$\mathbf{N}$ forms } & \multirow{3}{*}{ Bio } & \multicolumn{4}{|c|}{$\begin{array}{c}\mathrm{CO}_{2} \text { evolution } \\
(\mathrm{mg} / 100 \mathrm{gm} \text { dry soil/ } 24 \mathrm{hrs})\end{array}$} & \multicolumn{4}{|c|}{$\begin{array}{l}\text { Dehydrogenase activity (DHA) } \\
(\mu \mathrm{g} \text { TPF/ g dry soil/ } 24 \mathrm{hrs})\end{array}$} \\
\hline & & \multicolumn{2}{|c|}{2016} & \multicolumn{2}{|c|}{2017} & \multicolumn{2}{|c|}{2016} & \multicolumn{2}{|c|}{2017} \\
\hline & & $60 \mathrm{~kg} \mathrm{~N}$ & $30 \mathrm{~kg} \mathrm{~N}$ & $60 \mathrm{~kg} \mathrm{~N}$ & $30 \mathrm{~kg} \mathrm{~N}$ & $60 \mathrm{~kg} \mathrm{~N}$ & $30 \mathrm{~kg} \mathrm{~N}$ & $60 \mathrm{~kg} \mathrm{~N}$ & $30 \mathrm{~kg} \mathrm{~N}$ \\
\hline \multirow{4}{*}{ AS } & Control & $3.83 \mathrm{j}$ & $3.47 \mathrm{k}$ & $5.27 \mathrm{k}$ & $4.62 \mathrm{~m}$ & $7.20 \mathrm{j}$ & 6.641 & $7.62 \mathrm{j}$ & $6.78 \mathrm{n}$ \\
\hline & Azotobacter & $5.50 \mathrm{e}$ & $5.14 \mathrm{f}$ & $7.23 \mathrm{e}$ & $6.80 \mathrm{f}$ & $8.67 \mathrm{~d}$ & $8.58 \mathrm{~d}$ & $9.17 \mathrm{c}$ & $8.65 \mathrm{e}$ \\
\hline & Azospirillum & $5.03 \mathrm{f}$ & $4.70 \mathrm{~g}$ & $6.73 \mathrm{f}$ & $6.20 \mathrm{hi}$ & $8.18 \mathrm{f}$ & $7.63 \mathrm{~g}$ & $8.85 \mathrm{~d}$ & $8.20 \mathrm{~h}$ \\
\hline & Mixed & $7.60 \mathrm{a}$ & $7.07 \mathrm{~b}$ & $9.40 \mathrm{a}$ & $9.17 \mathrm{a}$ & $9.82 \mathrm{a}$ & $9.15 \mathrm{c}$ & $10.13 \mathrm{a}$ & $9.70 \mathrm{~b}$ \\
\hline \multirow{4}{*}{ AN } & Control & 2.801 & $2.20 \mathrm{~m}$ & $5.03 \mathrm{kl}$ & $4.30 \mathrm{n}$ & $6.35 \mathrm{~m}$ & $6.17 \mathrm{n}$ & $6.92 \mathrm{~m}$ & $6.37 \mathrm{o}$ \\
\hline & Azotobacter & $4.93 \mathrm{fg}$ & $4.30 \mathrm{~h}$ & $7.13 \mathrm{e}$ & $6.47 \mathrm{fg}$ & $8.27 \mathrm{f}$ & $7.70 \mathrm{~g}$ & $8.67 \mathrm{e}$ & $7.83 \mathrm{i}$ \\
\hline & Azospirillum & $4.27 \mathrm{~h}$ & $3.73 \mathrm{j}$ & $6.53 \mathrm{fg}$ & $5.93 \mathrm{ij}$ & $7.67 \mathrm{~g}$ & $7.38 \mathrm{~h}$ & $8.35 \mathrm{~g}$ & $7.75 \mathrm{i}$ \\
\hline & Mixed & $6.18 \mathrm{c}$ & $5.80 \mathrm{~d}$ & $8.73 \mathrm{~b}$ & $8.50 \mathrm{~b}$ & $9.28 \mathrm{~b}$ & $8.70 \mathrm{~d}$ & $9.62 \mathrm{~b}$ & $9.10 \mathrm{c}$ \\
\hline \multirow{4}{*}{ Urea-F } & Control & $2.30 \mathrm{~m}$ & $2.07 \mathrm{~m}$ & $4.77 \mathrm{~lm}$ & $3.87 \mathrm{o}$ & $5.60 \mathrm{o}$ & $5.10 \mathrm{p}$ & $6.35 \mathrm{o}$ & $5.85 \mathrm{p}$ \\
\hline & Azotobacter & $4.17 \mathrm{hi}$ & $4.00 \mathrm{ij}$ & $6.43 \mathrm{gh}$ & $6.23 \mathrm{~h}$ & $7.73 \mathrm{~g}$ & $7.25 \mathrm{ij}$ & $7.78 \mathrm{i}$ & 7.171 \\
\hline & Azospirillum & $3.85 \mathrm{j}$ & $3.40 \mathrm{k}$ & $5.80 \mathrm{j}$ & $5.23 \mathrm{k}$ & $7.37 \mathrm{hi}$ & $6.77 \mathrm{k}$ & $7.38 \mathrm{k}$ & $6.90 \mathrm{~m}$ \\
\hline & Mixed & $5.53 \mathrm{e}$ & $5.17 \mathrm{f}$ & $8.03 \mathrm{c}$ & $7.77 \mathrm{~d}$ & $8.68 \mathrm{~d}$ & $8.45 \mathrm{e}$ & $8.82 \mathrm{~d}$ & $8.50 \mathrm{f}$ \\
\hline
\end{tabular}

Mean values in the above table sharing one alphabet are not significantly different.

Plant height, number of leaves per plant, head diameter, and head dry weight as plant traits are presented in the following to support illustrating how the applied treatments could impose their influence on plant potential to respond to those treatments.

\section{Plant height and number of leaves}

Data in Table 5 show clear-cut effects on sunflower plant height that are as close as those exposed by the effects of applied treatments on soil available $\mathrm{N}, \mathrm{P}$, and $\mathrm{K}$ shown previously in table 2. Comprehensively, the best combination treatment was that composed of applying AS at the rate of $60 \mathrm{~kg} \mathrm{~N} /$ fed and inoculating with a mixture of Azotobacter chroococcum and Azospirillum lipoferum to produce the highest plants of sunflower grown on the soil of the new valley area. This finding held true for the two seasons of the current study. In conclusion, superiority of this combination treatment to accumulate the highest available $\mathrm{N}, \mathrm{P}$, and $\mathrm{K}$ and promoting the highest microbial counts of both Azotobacter and Azospirillum as pointed to by both of highest $\mathrm{CO}_{2}$ evolution and DHA in the rhizosphere under sunflower plants could acquire the highest potential for producing the highest plant height.

This finding held true for the measurements of number of leaves/plant in both seasons of study irrespective of the existence of some non-significant 2-variable interactions and the 3 -variable interaction in one or both seasons of study.

\section{Head diameter and head dry weight}

Data in Table 6 show clear-cut significant effects on sunflower head diameter related to $\mathrm{N}$ forms and biological fertilizers in both seasons of study. The higher application rate could not show significant difference from the lower one on the measurements of sunflower head diameter in both seasons of study. This finding declares that applying $\mathrm{N}$ forms at $60 \mathrm{~kg} \mathrm{~N} / \mathrm{fed}$ was as effective as that at $30 \mathrm{~kg} \mathrm{~N} / \mathrm{fed}$. Albeit economic in saving the amount of applied $\mathrm{N}$ sources, the previous plant traits discussed impose the ideology of applying them at the higher rate. Despite that some interactions could not show up as significant on the measurement of head diameter, the best combination treatment was that composed of applying AS at the rate of $60 \mathrm{~kg} \mathrm{~N} /$ fed and inoculating with a mixture of Azotobacter chroococcum and Azospirillum lipoferum to produce the highest head diameter of sunflower grown on the soil of the new valley area in both seasons of study.

Data in Table 6 tells also that the sunflower head dry weight could exhibit significant effects due to the application of $\mathrm{N}$ sources, application rate, and biofertilizer variables. Comprehensively, 
the best combination treatment could be figured out as applying AS at the rate of $60 \mathrm{~kg} \mathrm{~N} / \mathrm{fed}$ and inoculation with a mixture of Azotobacter chroococcum and Azospirillum lipoferum to obtain the highest dry weight of sunflower head.

Plant dry matter production, seed yield, and oil yield:

Data in Table 7 show clear-cut significant effects on sunflower dry matter production in both seasons of study. In other words AS significantly surpassed AN which, in turn, surpassed urea formaldehyde in producing the highest dry matter of sunflower plants. The higher rate significantly surpassed the lower in both seasons of study. With regard to bio-fertilization, both Azotobacter chroococcum and Azospirillum lipoferum surpassed the un-inoculated control treatment, with Azotobacter being the better of the two inoculants in effecting for the highest dry matter production of sunflower plants in both seasons. Amazing was that applying both inoculants together as mixed treatment surpassed the performance of both inoculants when they are separately applied. From another stand point, the three 2-variable interactions were consistently not significant. In other words these three interactions, could not translate the advantages that were described previously in this current research into significant influences on sunflower plant dry matter production in both seasons of study. This may be attributed to the clear-cut significant effects of sole variable of $\mathrm{N}$ sources, rates of application, and biological fertilizers on the production of dry matter production. It may also reflect the plants shifting to induce pollination and seed initiation and filling with redirection of plant manufactured food to perform seed maturation. Therefore, plants perform the senescence action through which they shift all nutrients from plant parts and move them toward seeds. This attitude seems to be emphasized by the observation regarding the 3 -variable interaction which showed up to be significant in producing dry matter of sunflower plants. Comprehensively, the best combination treatment was, consistently, that composed of applying AS at $60 \mathrm{~kg} \mathrm{~N} / \mathrm{fed}$ and inoculation with bio-fertilizer mixture of Azotobacter chroococcum and Azospirillum lipoferum to produce the highest significant dry matter by sunflower plants.

Data in Table 7 tells also that seed yield showed, more or less, the same influences of $\mathrm{N}$ sources and biofertilizer variables showed up as significant as those with plant dry weight as mentioned above. While the effect of application rates could not translate itself into significant effect on seed production. This may be referred to that the activities of the applied biofertilizers compensated for the gap in performance between the two adopted rates, especially in the final stages of plant life span. In other words, the fixed atmospheric $\mathrm{N}$ by the biofertilizers could mimic or hinder or make up the difference between the two rates of application. Comprehensively, the best combination treatment was, consistently, that composed of applying AS at $60 \mathrm{~kg} \mathrm{~N} / \mathrm{fed}$ and inoculation with bio-fertilizer mixture of Azotobacter chroococcum and Azospirillum lipoferum to produce the highest significant seed weight per plant of sunflower.

With respect to oil yield of sunflower plants grown on the soil of the new valley area, Table 7 tells also that oil yield reflected the directions of all applied treatments and their interactions, except for one interaction which is that between the application rate and the bio-fertilizers, which was not significant, in both seasons of study. Generally, the best combination treatment was, consistently, that composed of applying AS at $60 \mathrm{~kg} \mathrm{~N} / \mathrm{fed}$ and inoculation with bio-fertilizer mixture of Azotobacter chroococcum and Azospirillum lipoferum to produce the highest oil yield of sunflower plants.

\section{Seed N, P, and K contents of sunflower}

The calculated effects of single variables; $\mathrm{N}$ forms, rates of application, and bio-fertilizers, could be significant on accumulating $\mathrm{N}$, $\mathrm{P}$, and $\mathrm{K}$ in seeds of sunflower plants in both seasons of study as shown in Table 8.

In other words, AS was significantly better than AN, which, in turn, was better than urea-formaldehyde in inducing the highest concentrations of the three nutrients in sunflower seeds. Being the lowest in salt index but highest in acidifying the rhizosphere, AS could also render mild salt effect on the roots of the grown plants with proliferation of more available plant nutrients. In addition, the higher rate of $\mathrm{N}$ forms application was significantly better than the lower one. Inoculation with free-living microbes could consistently prove being significant on seed content of the three nutrients as compared with the control treatment. Azotobaacter chroococcum was significantly better than Azospirillum lipoferum in 
this respect when they are applied separately, but, the mixed application of both microbes together greatly surpassed applying them separately. The three 2-variable interactions could not play consistent role in accumulating the three nutrients in sunflower seeds. They showed intermittent significant pattern. The 3-variable interaction showed consistent non-significant role in this regard. Generally, the best combination treatment was, consistently, that composed of applying AS at $60 \mathrm{~kg} \mathrm{~N} /$ fed and inoculation with bio-fertilizer mixture of Azotobacter and Azospirillum to accumulate the highest $\mathrm{N}, \mathrm{P}$, and $\mathrm{K}$ nutrients in the seeds sunflower plants.

TABLE 5. Plant height (cm) and number of leaves/plant prior to sunflower harvest as affected by the applied treatments in 2016 and 2017

\begin{tabular}{|c|c|c|c|c|c|c|c|c|c|}
\hline \multirow{3}{*}{$\mathbf{N}$ forms } & \multirow{3}{*}{ Bio } & \multicolumn{4}{|c|}{ Plant height $(\mathrm{cm})$} & \multicolumn{4}{|c|}{ No. of leaves/plant } \\
\hline & & \multicolumn{2}{|c|}{2016} & \multicolumn{2}{|c|}{2017} & \multicolumn{2}{|c|}{2016} & \multicolumn{2}{|c|}{2017} \\
\hline & & $60 \mathrm{~kg} \mathrm{~N}$ & $30 \mathrm{~kg} \mathrm{~N}$ & $60 \mathrm{~kg} \mathrm{~N}$ & $30 \mathrm{~kg} \mathrm{~N}$ & $60 \mathrm{~kg} \mathrm{~N}$ & $30 \mathrm{~kg} \mathrm{~N}$ & $60 \mathrm{~kg} \mathrm{~N}$ & $30 \mathrm{~kg} \mathrm{~N}$ \\
\hline \multirow{4}{*}{ AS } & Control & $154 \mathrm{~g}$ & $139 \mathrm{j}$ & $155 \mathrm{j}$ & 1431 & $13 \mathrm{k}$ & $9 \mathrm{mn}$ & $17 \mathrm{kl}$ & $14 \mathrm{n}$ \\
\hline & Azotobacter & $193 \mathrm{~b}$ & $168 \mathrm{e}$ & $184 \mathrm{~b}$ & $177 \mathrm{f}$ & $30 \mathrm{~b}$ & $25 \mathrm{e}$ & $32 \mathrm{bc}$ & $27 \mathrm{f}$ \\
\hline & Azospirillum & $171 \mathrm{~d}$ & $161 \mathrm{f}$ & $185 \mathrm{~d}$ & $168 \mathrm{~g}$ & $27 \mathrm{~cd}$ & $23 \mathrm{f}$ & $29 \mathrm{e}$ & $25 \mathrm{~g}$ \\
\hline & Mixed & $197 \mathrm{a}$ & $178 \mathrm{c}$ & $202 \mathrm{a}$ & $187 \mathrm{c}$ & $34 \mathrm{a}$ & $30 \mathrm{~b}$ & $37 \mathrm{a}$ & $31 \mathrm{~cd}$ \\
\hline \multirow{4}{*}{ AN } & Control & $97 \mathrm{p}$ & $83 \mathrm{q}$ & $106 \mathrm{r}$ & $91 \mathrm{~s}$ & $10 \mathrm{~lm}$ & $8 \mathrm{n}$ & $16 \mathrm{~lm}$ & $11 \mathrm{hi}$ \\
\hline & Azotobacter & $161 \mathrm{f}$ & $146 \mathrm{~h}$ & $165 \mathrm{~h}$ & $149 \mathrm{k}$ & $25 \mathrm{e}$ & $21 \mathrm{gh}$ & $30 \mathrm{de}$ & $22 \mathrm{i}$ \\
\hline & Azospirillum & $153 \mathrm{~g}$ & $143 \mathrm{i}$ & $162 \mathrm{i}$ & 1431 & $22 \mathrm{fg}$ & $20 \mathrm{~h}$ & $25 \mathrm{~g}$ & $27 \mathrm{f}$ \\
\hline & Mixed & $171 \mathrm{~d}$ & $161 \mathrm{f}$ & $183 \mathrm{e}$ & $166 \mathrm{~h}$ & $28 \mathrm{c}$ & $26 \mathrm{de}$ & $33 \mathrm{~b}$ & $27 \mathrm{f}$ \\
\hline \multirow{4}{*}{ Urea-F } & Control & $62 \mathrm{r}$ & $52 \mathrm{~s}$ & $66 \mathrm{t}$ & $56 \mathrm{u}$ & $10 \mathrm{~lm}$ & $8 \mathrm{n}$ & $10 \mathrm{o}$ & $8 \mathrm{p}$ \\
\hline & Azotobacter & 1171 & $106 \mathrm{n}$ & $137 \mathrm{~m}$ & $121 \mathrm{p}$ & $18 \mathrm{i}$ & $16 \mathrm{j}$ & $20 \mathrm{j}$ & $15 \mathrm{mn}$ \\
\hline & Azospirillum & $113 \mathrm{~m}$ & $102 \mathrm{o}$ & $128 \mathrm{o}$ & $119 q$ & $16 \mathrm{j}$ & $14 \mathrm{k}$ & $18 \mathrm{k}$ & $15 \mathrm{mn}$ \\
\hline & Mixed & $' 142 \mathrm{i}$ & $125 \mathrm{k}$ & $148 \mathrm{k}$ & $133 n$ & $23 \mathrm{f}$ & $20 \mathrm{~h}$ & $24 \mathrm{gh}$ & $22 \mathrm{i}$ \\
\hline
\end{tabular}

Mean values in the above table sharing one alphabet are not significantly different.

TABLE 6. Head diameter $(\mathrm{cm})$ and dry weight $(\mathrm{gm})$ prior to sunflower harvest as affected by the applied treatments in 2016 and 2017

\begin{tabular}{|c|c|c|c|c|c|c|c|c|c|}
\hline \multirow{3}{*}{$\mathbf{N}$ forms } & \multirow{3}{*}{ Bio. } & \multicolumn{4}{|c|}{ Head diameter $(\mathrm{cm})$} & \multicolumn{4}{|c|}{ Head dry weight (gm) } \\
\hline & & \multicolumn{2}{|c|}{2016} & \multicolumn{2}{|c|}{2017} & \multicolumn{2}{|c|}{2016} & \multicolumn{2}{|c|}{2017} \\
\hline & & $60 \mathrm{~kg} \mathrm{~N}$ & $30 \mathrm{~kg} \mathrm{~N}$ & $60 \mathrm{~kg} \mathrm{~N}$ & $30 \mathrm{~kg} \mathrm{~N}$ & $60 \mathrm{~kg} \mathrm{~N}$ & $30 \mathrm{~kg} \mathrm{~N}$ & $60 \mathrm{~kg} \mathrm{~N}$ & $30 \mathrm{~kg} \mathrm{~N}$ \\
\hline \multirow{4}{*}{ AS } & Control & $21 \mathrm{~g}$ & $18 \mathrm{i}$ & $23 \mathrm{j}$ & $19 n$ & $9 \mathrm{f}$ & $6 \mathrm{~h}$ & $9 \mathrm{~h}$ & $8 \mathrm{i}$ \\
\hline & Azotobacter & $31 \mathrm{~b}$ & $23 \mathrm{e}$ & $33 \mathrm{~b}$ & $27 \mathrm{f}$ & $13 \mathrm{~b}$ & $11 \mathrm{~d}$ & $15 \mathrm{~b}$ & $12 \mathrm{e}$ \\
\hline & Azospirillum & $30 \mathrm{c}$ & $11 \mathrm{o}$ & $32 \mathrm{c}$ & $25 \mathrm{~h}$ & $12 \mathrm{c}$ & $10 \mathrm{e}$ & $14 \mathrm{c}$ & $11 \mathrm{f}$ \\
\hline & Mixed & $34 \mathrm{a}$ & $18 \mathrm{i}$ & $36 \mathrm{a}$ & $31 \mathrm{~d}$ & $14 \mathrm{a}$ & $14 \mathrm{a}$ & $16 \mathrm{a}$ & $15 \mathrm{~b}$ \\
\hline \multirow{4}{*}{ AN } & Control & 151 & $13 \mathrm{~m}$ & $16 \mathrm{p}$ & $16 \mathrm{p}$ & $7 \mathrm{~g}$ & $6 \mathrm{~h}$ & $9 \mathrm{~h}$ & $7 \mathrm{j}$ \\
\hline & Azotobacter & $19 \mathrm{~h}$ & $18 \mathrm{i}$ & $24 \mathrm{i}$ & $24 \mathrm{i}$ & $12 \mathrm{c}$ & $10 \mathrm{e}$ & $13 \mathrm{~d}$ & $11 \mathrm{f}$ \\
\hline & Azospirillum & $18 \mathrm{i}$ & $17 \mathrm{j}$ & 211 & 211 & $11 \mathrm{~d}$ & $9 \mathrm{f}$ & $13 \mathrm{~d}$ & $11 \mathrm{f}$ \\
\hline & Mixed & $23 \mathrm{e}$ & $22 \mathrm{f}$ & $28 \mathrm{e}$ & $26 \mathrm{~g}$ & $14 \mathrm{a}$ & $13 \mathrm{~b}$ & $14 \mathrm{c}$ & $13 \mathrm{~d}$ \\
\hline \multirow{4}{*}{ Urea-F } & Control & $11 \mathrm{o}$ & $12 \mathrm{n}$ & $13 \mathrm{r}$ & $14 \mathrm{q}$ & $6 \mathrm{~h}$ & $5 \mathrm{i}$ & $7 \mathrm{j}$ & $6 \mathrm{k}$ \\
\hline & Azotobacter & $18 \mathrm{i}$ & $16 \mathrm{k}$ & $20 \mathrm{~m}$ & 18 o & $11 \mathrm{~d}$ & $9 \mathrm{f}$ & $13 \mathrm{~d}$ & $10 \mathrm{~g}$ \\
\hline & Azospirillum & 151 & 151 & 18 o & $16 \mathrm{p}$ & $11 \mathrm{~d}$ & $9 \mathrm{f}$ & $12 \mathrm{e}$ & $10 \mathrm{~g}$ \\
\hline & Mixed & $19 \mathrm{~h}$ & $18 \mathrm{i}$ & $23 \mathrm{j}$ & $22 \mathrm{k}$ & $12 \mathrm{c}$ & $12 \mathrm{c}$ & $14 \mathrm{c}$ & $13 \mathrm{~d}$ \\
\hline
\end{tabular}

Mean values in the above table sharing one alphabet are not significantly different. 
TABLE 7. Plant dry weight (gm), seed yield ( $\mathrm{kg} / \mathrm{fed})$, and oil yield ( $\mathrm{kg} / \mathrm{fed})$ of sunflower as affected by the applied treatments in 2016 and 2017

\begin{tabular}{|c|c|c|c|c|c|c|c|c|c|c|c|c|c|}
\hline \multirow{3}{*}{$\begin{array}{l}N \\
\text { forms }\end{array}$} & \multirow{3}{*}{ Bio } & \multicolumn{4}{|c|}{ Plant dry weight (gm) } & \multicolumn{4}{|c|}{ Seed yield (kg/fed) } & \multicolumn{4}{|c|}{ Oil yield (kg/fed) } \\
\hline & & \multicolumn{2}{|c|}{2016} & \multicolumn{2}{|c|}{2017} & \multicolumn{2}{|c|}{2016} & \multicolumn{2}{|c|}{2017} & \multicolumn{2}{|c|}{2016} & \multicolumn{2}{|c|}{2017} \\
\hline & & 60 & 30 & 60 & 30 & 60 & 30 & 60 & 30 & 60 & 30 & 60 & 30 \\
\hline \multirow{4}{*}{ AS } & Control & 369 de & $321 \mathrm{gh}$ & $381 \mathrm{ef}$ & $330 \mathrm{~h}$ & 82 hi & 78 hij & $87 \mathrm{k}$ & $80 \mathrm{~lm}$ & $369 \mathrm{de}$ & $321 \mathrm{gh}$ & 381 ef & $330 \mathrm{~h}$ \\
\hline & Azotobacter & $393 \mathrm{~b}$ & $367 \mathrm{de}$ & $411 \mathrm{bc}$ & 393 de & $125 \mathrm{~b}$ & 114 de & $135 \mathrm{c}$ & $123 \mathrm{e}$ & $393 \mathrm{~b}$ & $367 \mathrm{de}$ & $411 \mathrm{bc}$ & $393 \mathrm{de}$ \\
\hline & Azospirillum & $385 \mathrm{c}$ & $361 \mathrm{e}$ & $391 \mathrm{de}$ & $373 \mathrm{f}$ & $121 \mathrm{bc}$ & $103 \mathrm{f}$ & $128 \mathrm{~d}$ & $114 \mathrm{fg}$ & $385 \mathrm{c}$ & $361 \mathrm{e}$ & $391 \mathrm{de}$ & $373 \mathrm{f}$ \\
\hline & Mixed & $413 \mathrm{a}$ & $414 \mathrm{a}$ & $424 \mathrm{a}$ & $418 \mathrm{ab}$ & $139 \mathrm{a}$ & $123 \mathrm{bc}$ & $155 \mathrm{a}$ & $140 \mathrm{~b}$ & $413 \mathrm{a}$ & $414 \mathrm{a}$ & $424 \mathrm{a}$ & $418 \mathrm{ab}$ \\
\hline \multirow{4}{*}{ AN } & Control & $280 \mathrm{kl}$ & $265 \mathrm{~m}$ & $289 \mathrm{k}$ & $260 \mathrm{n}$ & $67 \mathrm{k}$ & $67 \mathrm{k}$ & $78 \mathrm{mn}$ & $75 \mathrm{n}$ & $280 \mathrm{kl}$ & $265 \mathrm{~m}$ & $289 \mathrm{k}$ & $260 n$ \\
\hline & Azotobacter & $336 \mathrm{f}$ & $293 \mathrm{j}$ & $350 \mathrm{~g}$ & $309 \mathrm{ij}$ & $106 \mathrm{ef}$ & $84 \mathrm{gh}$ & $116 \mathrm{f}$ & $108 \mathrm{~h}$ & $336 \mathrm{f}$ & $293 \mathrm{j}$ & $350 \mathrm{~g}$ & $309 \mathrm{ij}$ \\
\hline & Azospirillum & $331 \mathrm{fg}$ & $289 \mathrm{jk}$ & $345 \mathrm{~g}$ & $302 \mathrm{j}$ & $89 \mathrm{~g}$ & 80 hi & $110 \mathrm{gh}$ & $100 \mathrm{i}$ & $331 \mathrm{fg}$ & $289 \mathrm{jk}$ & $345 \mathrm{~g}$ & $302 \mathrm{j}$ \\
\hline & Mixed & $375 \mathrm{~cd}$ & $313 \mathrm{hi}$ & $402 \mathrm{~cd}$ & $373 \mathrm{f}$ & $117 \mathrm{~cd}$ & $107 \mathrm{ef}$ & $126 \mathrm{de}$ & $122 \mathrm{e}$ & $375 \mathrm{~cd}$ & $313 \mathrm{hi}$ & $402 \mathrm{~cd}$ & $373 \mathrm{f}$ \\
\hline \multirow{4}{*}{ Urea-F } & Control & $242 \mathrm{o}$ & $242 \mathrm{o}$ & $240 \mathrm{o}$ & 2450 & $72 \mathrm{jk}$ & $66 \mathrm{k}$ & 68 o & 640 & $242 \mathrm{o}$ & $242 \mathrm{o}$ & $240 \mathrm{o}$ & 2450 \\
\hline & Azotobacter & 2771 & $264 \mathrm{mn}$ & $281 \mathrm{kl}$ & $277 \mathrm{klm}$ & $85 \mathrm{gh}$ & $77 \mathrm{ij}$ & $92 \mathrm{j}$ & $84 \mathrm{kl}$ & 2771 & $264 \mathrm{mn}$ & $281 \mathrm{kl}$ & $277 \mathrm{klm}$ \\
\hline & Azospirillum & $270 \mathrm{~lm}$ & 253 no & $270 \mathrm{lmn}$ & $267 \mathrm{mn}$ & 78 hij & $70 \mathrm{k}$ & $88 \mathrm{jk}$ & $79 \mathrm{mn}$ & $270 \mathrm{~lm}$ & 253 no & $270 \operatorname{lmn}$ & $267 \mathrm{mn}$ \\
\hline & Mixed & $308 \mathrm{i}$ & $295 \mathrm{j}$ & $348 \mathrm{~g}$ & $319 \mathrm{hi}$ & $105 \mathrm{f}$ & $89 \mathrm{~g}$ & $117 \mathrm{f}$ & $100 \mathrm{ij}$ & $308 \mathrm{i}$ & $295 \mathrm{j}$ & $348 \mathrm{~g}$ & $319 \mathrm{hi}$ \\
\hline
\end{tabular}

Mean values in the above table sharing one alphabet are not significantly different.

TABLE 8. N, P, and K contents of sunflower seeds as affected by the applied treatments in 2016 and 2017

\begin{tabular}{|c|c|c|c|c|c|c|c|c|c|c|c|c|c|}
\hline \multirow{3}{*}{$\begin{array}{l}\mathbf{N} \\
\text { forms }\end{array}$} & \multirow{3}{*}{ Bio. } & \multicolumn{4}{|c|}{ Seed N ( $\mu \mathrm{g} N / g m)$} & \multicolumn{4}{|c|}{$S P(\mu g P / g m)$} & \multicolumn{4}{|c|}{$S \mathrm{~K}(\mu \mathrm{g} \mathrm{K} / \mathrm{gm})$} \\
\hline & & \multicolumn{2}{|c|}{2016} & \multicolumn{2}{|c|}{2017} & \multicolumn{2}{|c|}{2016} & \multicolumn{2}{|c|}{2017} & \multicolumn{2}{|c|}{2016} & \multicolumn{2}{|c|}{2017} \\
\hline & & 60 & 30 & 60 & 30 & 60 & 30 & 60 & 30 & 60 & 30 & 60 & 30 \\
\hline \multirow{4}{*}{ AS } & Control & $2.82 \mathrm{i}$ & $2.40 \mathrm{kl}$ & $2.83 \mathrm{~m}$ & $2.33 \mathrm{n}$ & $0.29 \mathrm{j}$ & $0.23 \mathrm{o}$ & $0.33 \mathrm{~m}$ & $0.27 \mathrm{r}$ & $0.71 \mathrm{~m}$ & $0.62 \mathrm{e}$ & 0.741 & $0.67 \mathrm{n}$ \\
\hline & Azotobacter & $3.57 \mathrm{bc}$ & $3.37 \mathrm{de}$ & $3.68 \mathrm{bcde}$ & $3.48 \mathrm{fg}$ & $0.40 \mathrm{c}$ & $0.33 \mathrm{~h}$ & $0.44 \mathrm{~d}$ & $0.38 \mathrm{~h}$ & $0.87 \mathrm{c}$ & $0.83 \mathrm{e}$ & $0.92 \mathrm{~b}$ & $0.85 \mathrm{f}$ \\
\hline & Azospirillum & $3.28 \mathrm{ef}$ & $3.03 \mathrm{~g}$ & $3.32 \mathrm{~h}$ & $3.13 \mathrm{ij}$ & $0.55 \mathrm{~g}$ & $0.31 \mathrm{i}$ & $0.4 \mathrm{e}$ & 0.341 & $0.81 \mathrm{f}$ & $0.77 \mathrm{i}$ & $0.86 \mathrm{e}$ & $0.80 \mathrm{i}$ \\
\hline & Mixed & $3.95 \mathrm{a}$ & $3.57 \mathrm{bc}$ & $4.07 \mathrm{a}$ & $3.70 \mathrm{bcd}$ & $0.43 \mathrm{a}$ & $0.36 \mathrm{f}$ & $0.53 \mathrm{a}$ & $0.46 \mathrm{c}$ & $092 \mathrm{a}$ & $0.88 \mathrm{~b}$ & $0.95 \mathrm{a}$ & $0.89 \mathrm{c}$ \\
\hline \multirow{4}{*}{ AN } & Control & $2.57 \mathrm{j}$ & 2.331 & $3.03 \mathrm{jkl}$ & $2.28 \mathrm{n}$ & $0.25 \mathrm{~m}$ & $0.20 \mathrm{q}$ & $0.29 \mathrm{p}$ & $0.24 \mathrm{~s}$ & $0.65 n$ & $0.57 \mathrm{q}$ & $0.71 \mathrm{~m}$ & $0.65 \mathrm{o}$ \\
\hline & Azotobacter & $3.40 \mathrm{de}$ & $3.13 \mathrm{fg}$ & $3.57 \mathrm{def}$ & $3.35 \mathrm{gh}$ & $0.37 \mathrm{e}$ & $0.31 \mathrm{i}$ & $0.41 \mathrm{f}$ & $0.37 \mathrm{i}$ & $0.84 \mathrm{~d}$ & $0.80 \mathrm{~g}$ & $0.86 \mathrm{e}$ & $0.82 \mathrm{~g}$ \\
\hline & Azospirillum & $3.10 \mathrm{~g}$ & $2.87 \mathrm{hi}$ & $3.15 \mathrm{ij}$ & $3.07 \mathrm{jk}$ & $0.33 \mathrm{~h}$ & $0.27 \mathrm{k}$ & $0.40 \mathrm{~g}$ & $0.32 \mathrm{n}$ & $0.77 \mathrm{i}$ & 0.731 & $0.81 \mathrm{~h}$ & $0.78 \mathrm{j}$ \\
\hline & Mixed & $3.63 \mathrm{~b}$ & $3.45 \mathrm{~cd}$ & $3.82 \mathrm{~b}$ & $3.63 \mathrm{cde}$ & $0.41 \mathrm{~b}$ & $0.35 \mathrm{~g}$ & $0.48 \mathrm{~b}$ & $0.44 \mathrm{~d}$ & $0.88 \mathrm{~b}$ & $0.84 \mathrm{~d}$ & $0.92 \mathrm{~b}$ & $0.86 \mathrm{e}$ \\
\hline \multirow{4}{*}{ Urea-F } & Control & $2.52 \mathrm{jk}$ & 2.281 & $2.97 \mathrm{kl}$ & $2.22 \mathrm{n}$ & $0.24 \mathrm{n}$ & $0.21 \mathrm{p}$ & $0.28 \mathrm{q}$ & $0.22 \mathrm{t}$ & $0.63 \mathrm{o}$ & $0.56 \mathrm{r}$ & $0.65 \mathrm{o}$ & $0.62 \mathrm{p}$ \\
\hline & Azotobacter & $3.33 \mathrm{de}$ & $3.10 \mathrm{~g}$ & $3.48 \mathrm{fg}$ & $3.22 \mathrm{hi}$ & $0.36 \mathrm{f}$ & $0.29 \mathrm{j}$ & $0.38 \mathrm{~h}$ & $0.35 \mathrm{k}$ & $0.79 \mathrm{~h}$ & $0.76 \mathrm{j}$ & $0.82 \mathrm{~g}$ & $0.80 \mathrm{i}$ \\
\hline & Azospirillum & $3.02 \mathrm{gh}$ & $2.75 \mathrm{i}$ & $3.07 \mathrm{jk}$ & $2.90 \mathrm{~lm}$ & $0.31 \mathrm{i}$ & 0.261 & $0.36 \mathrm{j}$ & $0.31 \mathrm{o}$ & $0.74 \mathrm{k}$ & $0.71 \mathrm{~m}$ & $0.78 \mathrm{j}$ & $0.77 \mathrm{k}$ \\
\hline & Mixed & $3.58 \mathrm{bc}$ & $3.37 \mathrm{de}$ & $3.75 \mathrm{bc}$ & $3.55 \mathrm{def}$ & $0.39 \mathrm{~d}$ & $0.33 \mathrm{~h}$ & $0.46 \mathrm{c}$ & $0.41 \mathrm{f}$ & $0.87 \mathrm{c}$ & $0.83 \mathrm{e}$ & $0.88 \mathrm{~d}$ & $0.85 \mathrm{f}$ \\
\hline
\end{tabular}




\section{Conclusion}

This research work was conducted in two successive seasons (2016/2017) at the new valley research station of the Desert Research Centre (DRC) on a soil characterized by hot atmospheric conditions. The aim of this work was to feed sunflower plants to attain good vegetative growth, achieve the highest possible seed and oil yields, and be able to combat or loop around the adverse effects dominating the study area. The current study found that the combination treatment composed of applying AS at $60 \mathrm{~kg} \mathrm{~N} / \mathrm{fed}$ and inoculating with bio-fertilizer mixture of Azotobacter chroococcum and Azospirillum lipoferum, which is capable of fixing atmospheric nitrogen, then release it into the rhizosphere hosting plant roots, could proliferate highest soil available $\mathrm{N}, \mathrm{P}$, and $\mathrm{K}$ in the rhizosphere under sunflower plants. It could be significantly accommodate the highest biological activity that was evidenced by highest total Azotobacter chroococcum counts, highest $\mathrm{CO}_{2}$ evolution, and highest dehydrogenase (DHA). This treatment could be prelude to the highest plants with highest number of leaves per plant, largest head diameter and head dry weight, plant dry matter production, seed yield, and oil yield. Same treatment could accumulate $\mathrm{N}, \mathrm{P}$, and $\mathrm{K}$ in sunflower seeds. Apparently, this combination treatment seemed able to combat the adverse environmental conditions dominating the study area at the new valley region.

\section{References}

Abdel-Motagally, F.M.F., Osman, E.A. (2010) Effect of nitrogen and potassium fertilization combination of productivity of two sunflower cultivars under east of El-ewinate conditions. Amer. Eurasian J. Agric. \& Enviro. Scie. 8(4), 397-401.

Abd El-Rahman, Lamyaa A., Sayed, Dalia A., Ewais, Magda A. (2016) Seed yield and quality of sunflower (Helianthus annuus L.) as influened by integrated mineral and organic nitrogen fertilization systems. J. Soil Sci. and Agric. Eng., Mansoura Univ. 7(1), 53-63.

Cappuccino, J.C., Sherman, N. (1992) In: "Microbiology: A Laboratory Manual", New York, pp. 125-179.

FAO (1991) Fertigation/Chemigation. Proc. Export Consultation on Fertigation/Chemigation. 8-11
Sept., Cairo, Egypt, pp. 210-214.

Gendy, A.S.H., Hussein, A.H. Said-Al Ahl, Abeer A.M., Mohamed, Hanaa F.Y. (2013) Effect of some nitrogen sources, bio-fertilizers and their interaction on the growth, seed yield and chemical composition of Guar plants. Life Sci. J. 10(3), 389402.

Hamza, M.A.M., Abd-Elhady, E.S.E. (2010) Effect of organic and inorganic fertilization on vegetative growth and volatile oil of marjoram (Majorana hortensis L.) plant. J .Soil Scie. Agric. Engineering, 1(8), 839-851.

Herrera, J.M., Rubio, G., Häner, Lilia L., Delgado, J.A., Lucho-Constantino, C.A., Islas-Valdez, Samira, Pellet, D. (2016) Emerging and established technologies to increase nitrogen use efficiency of cereals. Agronomy, 6(2), 25.

Isobe, K., Ohte, N. (2014) Ecological perspectives on microbes involved in N-cycling. Microbes Environ. 29, 4-16

Jackson, M.L. (1973) "Soil Chemical Analysis"., pp. 38-56. Printice Hall, Inc., Englewood Cliffs, N.J. Library of Congress, USA.

Ju, X.T., Xing, G.X., Chen, X.P., Zhang, S.L., Zhang, L.J., Liu, X.J., Cui, Z.L., Yin, B., Christie, P., Zhu, Z.L. (2009) Reducing environmental risk by improving $\mathrm{N}$ management in intensive Chinese agricultural systems. Proc. Natl. Acad. Sci. USA, 106, 3041-3046.

Krieg, N.R., Dobereiner, J. (1984) The genus Azospirillum, "Bergey's Manual of Systematic Bacteriology" Vol. 1., N.R. Krieg \& J.G. Holt (Eds.), pp. 194-104. The Williams \& Wilkins Co., Baltimore.

Kargar, M., Kargar, M., Nowrooznejad, M.J., Ayazpour, K. (2014) The role of Azotobacter chrococcum and Azotobacter paspali on wheat growth in Fars Province. Adv. Environ. Biol. 8(17), 837-841.

Lucas, R.E., Vitosh, M.L. (1984) Salt index of fluid fertilizers, liquids and suspensions. Extension Bulletin E-933, Michigan State Univ., USA.

Mehran, M., Ardakani, Mohammad R., Madani, H., Zahedi, M., Amirabadi, M., Mafakheri, S. (2011) Response of sunflower yield and phytohormonal 
changes to Azotobacter, Azospirillum, Pseudomonas and animal manure in a chemical free agroecosystem. Annals of Biological Research, 2(6), 425-430.

Munir, M.A., Malik, M.A., Saleem, M.F. (2007) Impact of integration of crop manuring and nitrogen application on growth, yield and quality of spring planted sunflower (Helianthus annuus L.). Pak. J. Bot. 39, 41-449.

Nicoulaud, B.A.L., Bloom, A.J. (1996) Absorption and assimilation of foliarly applied urea in tomato. $J$. Amer. Soc. Hort. Sci. 121(6), 1117-1121.

Olsen, S.R., Cole, C.J., Watanabe, F.S., Dean, L.A. (1982) Estimation of available phosphorus in soils by extraction with sodium bicarbonate. Circ. No. 939, USDA. U.S. Government Printing Office, Washington, DC.

Onken, A.B., Sunderman, H.D. (1977) Colorimetric determinations of exchangeable ammonium, urea, nitrate, and nitrite in a single soil extract. Agron. J. 69, 49-53.

Page, A.L., Miller, R.H., Keeney, D.R. (1982) "Methods of Soil Analysis. Part 2: Chemical and
Microbiological Properties". $2^{\text {nd }}$ ed., Madison, Wisconson, U.S.A.

Pramer, D., Schmidt, E.L. (1964) "Experimental Soil Microbiology". Burgess Publ. Co., Minnesota, USA.

SPSS (2014) https://www.ibm.com/analytics/spssstatistics-software.

Thalmann, A. (1967) Uber die microbiello Akivitat undihr Beziehung $\mathrm{Zu}$ fruchtbartkeits merkmalen eini-ger Acherboden unter besonderer Berucksi chtigung der dehydrogenase akativitat (TTC. Redukation). Biss Gieben PH.D. Thesis. W. Germany.

Vessey, J.K. (2003) Plant growth promoting rhizobacteria as bio fertilizers. Plant Soil, 255, 571586.

Walkley, A., Black, I.A. (1934) An examination of Degtjareff method for determining soil organic matter and a proposed modification of the chromic acid titration method. Soil Sci. 37, 29-37.

$$
\begin{aligned}
& \text { تأثير اللقاحات الحيوية والصور المختلفة من الأسمدة النيتروجينية على إنتاجية وجودة نبات }
\end{aligned}
$$

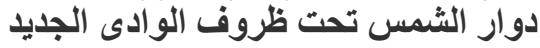

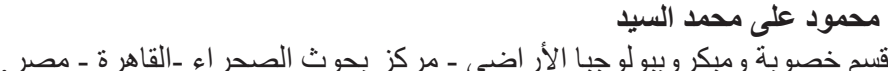

تم تتفيذ البحث خلال موسمين منتاليين عامى 2016/2017 بمحطة بحوث الو ادي الجديد التابعة لمركز بحوث

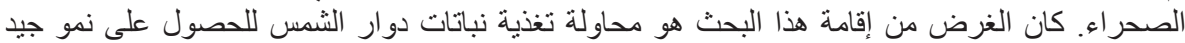

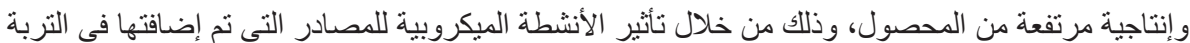

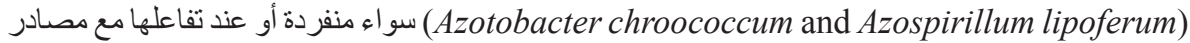

$$
\text { الأسمدة الأزونية المستخدمة (نترات الأمنيوم، سلفات الأمونيوم، يوريا فورمالدهيد). }
$$

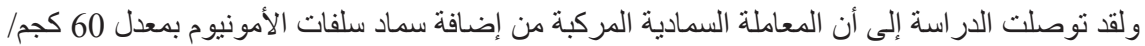

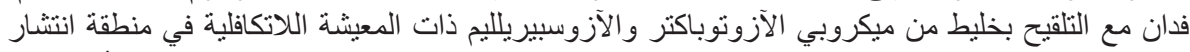

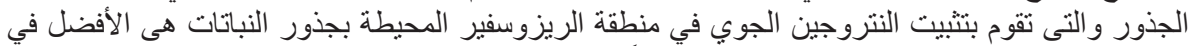

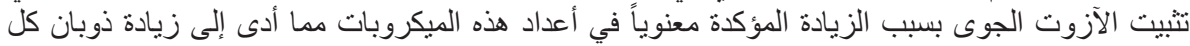

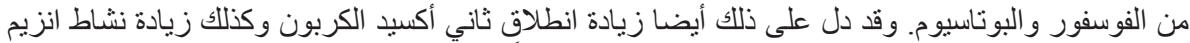

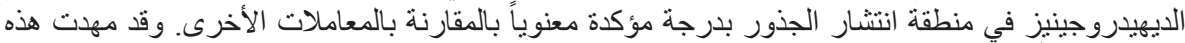

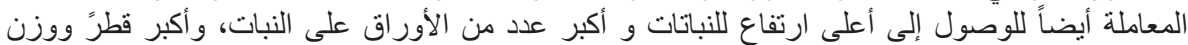

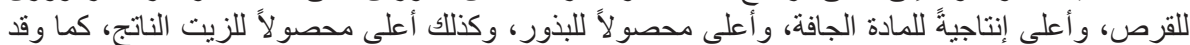

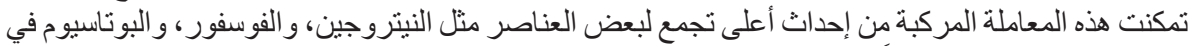

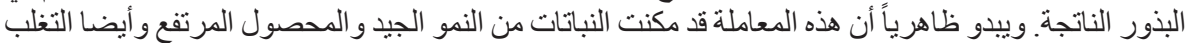
على الظروف الصعبة السائدة بمنطقة الدر اسة بالمقارنة بالمعاملات الأخرى في هذا العمل البحثي. 